\title{
Flood disasters: lessons from the past-worries for the future
}

\section{Gerhard Berz}

\section{J. R. Ni, Peking University}

\section{A. G. L. Borthwick, Oxford University}

In this paper, the author addresses the extremely important topic of recent trends in flood disasters, and their underlying causes. We have a similar interest in this topic with regard to river flooding in China.

During the past decade, China experienced a marked increase in flood disasters in terms of occurrence frequency and economic loss. In 1991, floods in the Yangtze, Huaihe and Songhua Rivers led to losses exceeding US\$8 billion. In 1998, the catastrophic flooding along the Yangtze and Songhua Rivers resulted in over US $\$ 30$ billion worth of damage, and were the worst floods experienced by China in 44 years. There has nevertheless been a very noticeable decline in the general trend of flood-related deaths. Consider the Yangtze River. In 1931, a large flood killed 145492 people and affected more than 28 million others. In 1954, 33000 died and 9.2 million people were affected. In 1998, the record flood affected 240 million people, but the death toll was greatly reduced to just over 3656 .

A striking feature of recent Chinese flood disasters is the increase in flood frequency (well beyond that anticipated using traditional forecasting models) caused by increasing river sedimentation rather than increasing rainfall. ${ }^{1}$ This has created the unusual phenomenon of large-scale flooding arising from relatively low river discharges. These sediment-enhanced floods result directly from deforestation and severe soil erosion along the floodplains and in the upper catchments. For instance, the bed of the Lower Yellow River is rising at a rate of $0 \cdot 1 \mathrm{~m}$ per year due to the deposition of 400 million $t$ of sediment, originating from the upper river catchments. This sediment deposition has significantly raised the peak flood level while also substantially reducing the river's flood-release capacity. For example, the maximum water level of the Yellow River due to a small flood in 1996 (with peak discharge of $7860 \mathrm{~m}^{3} / \mathrm{s}$, equivalent to a 1-in-2 year flood) was $0.91 \mathrm{~m}$ higher than that due to an extremely large flood in 1958 (with peak discharge of $22300 \mathrm{~m}^{3} / \mathrm{s}$, equivalent to a 1-in-70 year return period). A significant reduction in flood release velocity has also been observed. In the Yellow River, the time needed to release flow from Huayuankou (located in the lower reach) to the delta was 18 days in 1996, while that in 1958 was only 7 days.

Furthermore, sediment deposition and large-scale reclamation has also resulted in shrinkage of rivers and lakes, thus reducing their detention capability.
Investment in flood-control engineering construction has varied according to the level of economic loss incurred due to previous disasters. Between 1991 and 1997, the Chinese government invested US $\$ 13$ billion in water conservation at a $20 \%$ annual growth rate on average, which was equivalent to $1 \%$ of the total allocated for all infrastructure projects. Before dyke reinforcement, the levees and embankments were only capable of withstanding major floods once every 20 to 30 years, and flood-control facilities were substandard in 70\% of more than 600 flood-prone cities. More than 20000 reservoirs were believed to have weak spots. Countermeasures were, and still are, also needed to mitigate the impact of river and lake shrinkage.

In 1998, Chinese insurance companies were proactive in helping insured enterprises to move their property to safe places before the floods struck. Although there has been a trend towards greatly increased compensation for flood losses, Chinese industry is still only partially aware of the role of insurance in lessening risks. In flood diversion or detention areas, emergency diversion programmes require the evacuation of people and may lead to subsequent property loss. In 1998, over 250000 residents in the Jingjiang Flood Diversion Zone were relocated to safe areas to leave the way open for a possible diversionary discharge of excess water from the Yangtze River. Insurance in these areas was closely related to people's benefits and the regional development strategy. There is clearly a big potential market for flood-related insurance in China in the coming years, given the pace of economic development and the increasing frequency of floods. It is anticipated that insurance companies could form the backbone of the compensation system while the government offers policy support including tax deductions for flood insurance and sets up a flood compensation reserve fund.

Bearing in mind the existing conditions in China, decisionmaking has to be made in terms of different time spans. In the short-term, engineering measures and a regulatory framework are most useful. In the longer-term, water and soil conservation must be addressed from ecological and environmental perspectives. Reforestation of the catchments of large rivers is a priority, and so the Chinese government has urged certain key forestry enterprises to stop logging and instead to start planting trees in sensitive areas. An action plan has also been devised for the conversion of land use, whereby rivers and lakes converted into farmland would be restored to their original size 
so as to strengthen the flood adjustment capability. Further non-structural flood prevention measures need to be devised to achieve a proper balance between integrated ecosystem conservation and economic development. Since it is almost impossible to move all residents out of flood-prone areas, the problem becomes how to optimise land use in the restricted development area and how to establish an effective insurance system. To solve the special problems encountered in China, there is clearly a need for a partnership (of the kind envisaged by Dr Berz) between administrators, engineers, scientists and insurers. This partnership would need to cover a wide range of aspects including integrated river basin and floodplain management, sediment hazard analysis, real-time flood forecasting, rapid risk assessment, and post-disaster insurance and reinsurance.

\section{Authors' reply}

We appreciate very much Ni's and Borthwick's comments and share their opinion in practically all points. Nevertheless we would like to add some points.

The reduction of fatalities due to flood events can be attributed to improvements in forecasting and early warning during the past decades, a development that is valid for most of the world. In this context, one should not forget that not only were the number of deaths reduced, but, at the same time, the number of people in flood-prone areas has become much higher.

For Chinese rivers, sedimentation indeed seems to be one of the main reasons why flood frequencies increase. Deforestation in the upper catchments was often blamed for increased flooding on account of the fact that the bare landscape could not retain as much water as in former years. While this is certainly true to some extent, the much more serious consequence is the loss of protection against erosion afforded by vegetation. This erosion is the source of the material that is deposited in the lower reaches of the Yangtze.

We are convinced that, for flood losses, an even more important factor than the increased frequency of high water levels is the fact that much of the land formerly occupied by water is now covered with settlements. The area of waters between Yichang and Jingjiang has been reduced from $10000 \mathrm{~km}^{2}$ in 1949 to $2600 \mathrm{~km}^{2}$ today because of siltation and land reclamation. The Jingjiang diversion area is probably the best example. The area was originally-in the early fiftiesdesigned to receive diverted flood waters. Today the area can hardly be used for this purpose, because hundreds of thousands of people live there. Of course, their flood exposure is extremely high. It will be very difficult-if not impossible-to provide insurance cover for people like them. They would be 'too risky' for any insurance company.

We fully agree to the commentators' statement that the insurance industry could form the backbone of a compensation system for flood-related losses. Given the almost country-wide threat China certainly needs assistance from the international insurance sector, in particular from reinsurance companies which have combined scientific and insurance-related expertise. They not only take a large part of the financial burden, but also are able and willing to assist in designing tailor-cut insurance structures for the very large potential market in China.

In countries with an income structure like China it is even more difficult to establish a proper insurance system than in countries with more evenly spread incomes. Adverse selection and lack of financial resources to afford insurance may become prohibitive for any insurance scheme. As large parts of the populated areas are threatened by natural disasters-not only by floods, but also by earthquakes, droughts, landslides, hailstorms, typhoons etc.-an insurance package including the different natural hazards is certainly worth to be considered. Insurance alone, however, cannot solve the problems. Therefore, we again would like to stress the need for a balanced partnership towards loss and risk reduction that involves state and local authorities, the government, scientists and engineers, individuals and companies as well as insurance and reinsurance companies.

\section{REFERENCE}

1. Ni J. R., WANG Z. Y. and WANG G. Q. Mechanisms and control strategies of river disasters induced by sediment movement. Science Foundation in China, 1999, 1, 43-46. 